УДК 66.081.312.32

DOI: 10.30838/ P. CMM.2415.250918.69.133

\title{
СОРБЦІЯ ІОНІВ АМОНІЮ НА ПОВЕРХНІ ДИСПЕРСНИХ ГЛИНИСТИХ МІНЕРАЛІВ
}

\author{
АНДРОНОВ В. А. ${ }^{1}$, д. т. н., проф. \\ ДАНЧЕНКО Ю. М. ${ }^{2^{*}}, \kappa . m$. н., доч. \\ ОБІЖЕНКО Т. М. ${ }^{3}, \kappa . m$. н., доu. \\ УМАНСЬКА Т. I. ${ }^{4}, \kappa$. x. н., дои. \\ ОГРАПІШВІЛІ І. Г. ${ }^{5}$, мazicmp
}

\begin{abstract}
${ }^{1}$ Науково-дослідний центр, Національний університет цивільного захисту України, вул. Чернишевська, 94, 61023, Харків, Україна, тел. +38 (057) 704-18-02, e-mail: va andronov@ukr.net, ORCID ID: 0000-0001-7486-482X

${ }^{2}$ Кафедра загальної хімії, Харківський національний університет будівництва та архітектури, вул. Сумська, 40, 61002, Харків, Україна, тел. +38 (057) 706-20-81, e-mail: u_danchenko@ukr.net, ORCID ID: 0000-0003-3865-2496

${ }^{3}$ Кафедра загальної хімії, Харківський національний університет будівництва та архітектури, вул. Сумська, 40, 61002, Харків, Україна, тел. +38 (057) 706-20-81, e-mail: obigenko@ukr.net, ORCID ID: 0000-0002-1409-7515

${ }^{4}$ Кафедра загальної хімії, Харківський національний університет будівництва та архітектури, вул. Сумська, 40, 61002, Харків, Україна, тел. +38 (057) 706-20-81, e-mail: knuba.chemistry@gmail.com, ORCID ID: 0000-0002-2582-8416

${ }^{5}$ Кафедра теплогазопостачання, вентиляції та використання теплових вторинних енергоресурсів, Харківський національний університет будівництва та архітектури, вул. Сумська, 40, 61002, Харків, Україна, тел. +38 (057) 700-16-40, e-mail: iliya_ograpiani@ukr.net, ORCID ID: 000-0003-0798-5001
\end{abstract}

Mema. Встановлення закономірностей сорбції іонів $\mathrm{NH}_{4}{ }^{+}$на поверхні дисперсних глинистих мінералів різної хімічної природи (сорбентів). З'ясувати взаємозв'язок між кислотно-основними властивостями активних центрів гідроксильно-гідратного поверхневого шару сорбентів та ефективністю вилучення іонів $\mathrm{NH}_{4}^{+} 3$ водних розчинів. Методика. Для дослідження поверхневих і фізико-хімічних властивостей глинистих сорбентів використовувались сучасні методи: рентгенофазовий аналіз, електронна скануюча мікроскопія, потенціометричний аналіз водних суспензій, спектрофотометричний аналіз. Дослідження сорбційної здатності глинистих сорбентів по відношенню до іонів $\mathrm{NH}_{4}{ }^{+}$проводились у статичних умовах. Результати. Отримані результати експериментального дослідження мінерального складу, морфології поверхні, дисперсності, питомої поверхні, кислотноосновних властивостей гідроксильно-гідратного поверхневого шару дисперсних глинистих мінеральних сорбентів. Надана порівняльна характеристика ефективності використання глинистих сорбентів різної хімічної природи для вилучення іонів $\mathrm{NH}_{4}^{+}{ }_{3}$ водних розчинів. Встановлено, що сорбційна здатність глинистих сорбентів зростає у ряду бентонітова глина > каолінова глина > діабазова мука. Встановлено, що основним механізмом сорбції іонів $\mathrm{NH}_{4}{ }^{+}$на поверхні каолінової глини є іонний обмін, а на поверхні діабазової муки - фізична адсорбція. У водних суспензіях бентонітової глини реалізується змішаний механізм: фізична адсорбція і іонний обмін. Наукова новизна. Встановлені механізми та закономірності сорбції іонів $\mathrm{NH}_{4}^{+}$на поверхні глинистих сорбентів: бентонітової глини, каолінової глини і діабазової муки. Виявлені взаємозв'язки між мінеральним складом і будовою гідроксильно-гідратного поверхневого шару сорбентів. Показано, що механізм вилучення іонів $\mathrm{NH}_{4}{ }^{+}$обумовлений кількістю і кислотно-основними властивостями поверхневих активних центрів гідроксильно-гідратного шару сорбентів. Практична значимість. Встановлені закономірності дозволять більш ефективно використовувати дешеві та екологічно привабливі дисперсні глинисті мінерали в якості сорбентів для очистки рідких і газоподібних середовищ від іонів $\mathrm{NH}_{4}^{+}$.

\section{СОРБЦИЯ ИОНОВ АММОНИЯ НА ПОВЕРХНОСТИ ДИСПЕРСНЫХ ГЛИНИСТЫХ МІНЕРАЛОВ}

\author{
АНДРОНОВ В. А. ${ }^{1}$, д. m. н., проф.

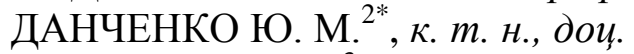

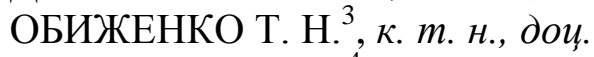

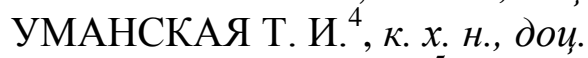 \\ ОГРАПИШВИЛИ И. Г. ${ }^{5}$, магистр
}

\footnotetext{
${ }^{1}$ Научно-исследовательский центр, Национальный университет гражданской защиты Украины, ул. Чернышевская, 94, 61023, Харьков, Украина, тел. +38 (057) 704-18-02, e-mail: va_andronov@ukr.net, ORCID ID: 0000-0001-7486-482X

${ }^{2}$ Кафедра общей химии, Харьковский национальный университет строительства и архитектуры, ул. Сумская, 40, 61002, Харьков, Украина, тел. +38 (057) 706-20-81, e-mail: u__danchenko@ukr.net, ORCID ID: 0000-0003-3865-2496
} 
${ }^{3}$ Кафедра общей химии, Харьковский национальный университет строительства и архитектуры, ул. Сумская, 40, 61002 , Харьков, Украина, тел. +38 (057) 706-20-81, e-mail: obigenko@ukr.net, ORCID ID: 0000-0002-1409-7515

${ }^{4}$ Кафедра общей химии, Харьковский национальный университет строительства и архитектуры, ул. Сумская, 40, 61002, Харьков, Украина, тел. +38 (057) 706-20-81, e-mail: knuba.chemistry@ gmail.com, ORCID ID: 0000-0002-2582-8416

${ }_{5}^{5}$ Кафедра теплогазоснабжения, вентиляции и использования тепловых вторичных энергоресурсов, Харьковский национальный университет строительства и архитектуры, ул. Сумская, 40, 61002, Харьков, Украина, тел. +38 (057) 700-16-40, e-mail: iliya ograpiani@ukr.net, ORCID ID: 000-0003-0798-5001

Цель. Определение закономерностей сорбции ионов $\mathrm{NH}_{4}{ }^{+}$на поверхности дисперсных глинистых минералов различной химической природы (сорбентов). Установление взаимосвязи между кислотно-основными свойствами активных центров гидроксильно-гидратного поверхностного слоя сорбентов и эффективностью извлечения ионов $\mathrm{NH}_{4}^{+}$из водных растворов. Методика. Для исследования поверхностных и физико-химических свойств глинистых сорбентов использовались современные методы: рентгенофазовый анализ, электронная сканирующая микроскопия, потенциометрический анализ водных суспензий, спектрофотометрический анализ. Исследование сорбционной способности глинистых сорбентов по отношению к ионам $\mathrm{NH}_{4}{ }^{+}$проводились в статических условиях. Результаты. Получены результаты экспериментальных исследований минерального состава, морфологии поверхности, дисперсности, удельной поверхности, кислотно-основных свойств гидроксильно-гидратного поверхностного слоя дисперсных глинистых минеральных сорбентов. Получена сравнительная характеристика эффективности использования глинистых сорбентов различной химической природы для извлечения ионов $\mathrm{NH}_{4}^{+}$ из водных растворов. Установлено, что сорбционная способность глинистых сорбентов возрастает в ряду бентонитовая глина > каолиновая глина > диабазовая мука. Установлено, что основным механизмом сорбции ионов $\mathrm{NH}_{4}{ }^{+}$на поверхности каолиновой глины является ионный обмен, а на поверхности диабазовой муки - физическая адсорбция. В водных суспензиях бентонитовой глины реализуется смешанный механизм: физическая адсорбция и ионный обмен. Научная новизна. Установлены механизмы и закономерности сорбции ионов $\mathrm{NH}_{4}^{+}$на поверхности глинистых сорбентов: бентонитовой глины, каолиновой глины и диабазовой муки. Определена взаимосвязь между минеральным составом и строением гидроксильногидратного поверхностного слоя сорбентов. Показано, что механизм извлечения ионов $\mathrm{NH}_{4}^{+}$обусловлен количеством и кислотно-основными свойствами поверхностных активных центров гидроксильно-гидратного слоя сорбентов. Практическая значимость. Полученные закономерности позволят более эффективно использовать дешевые и экологически привлекательные дисперсные глинистые минералы в качестве сорбентов для очистки жидких и газообразных сред от ионов $\mathrm{NH}_{4}{ }^{+}$.

\title{
SORPTION OF AMMONIUM IONS ON THE SURFACE OF DISPERSED CLAY MINERALS
}

\author{
ANDRONOV V. A. ${ }^{1}$, D. Sc. (Tech.), Prof., \\ DANCHENKO Yu. M. ${ }^{2 *}$, Ph. D, Assoc. Prof., \\ OBIGENKO T. M. ${ }^{3}$, Ph. D, Assoc. Prof., \\ UMANSKA T. I. ${ }^{4}$, Ph. D, Assoc. Prof., \\ OHRAPISHVILI I. H. ${ }^{5}, M . S c$.
}

${ }^{1}$ Research Center, National University of Civil Protection of Ukraine, Chernyshevska str., 94, Kharkiv, Ukraine, 61023 , phone: +38 (057) 704-18-02, e-mail: va_andronov@ukr.net, ORCID ID: 0000-0001-7486-482X

${ }^{2}$ Department of General Chemistry, Kharkiv National University of Civil Engineering and Architecture, Sumska str., 40, Kharkiv, Ukraine, 61002, phone: +38 (057) 706-20-81, e-mail: u_danchenko@ukr.net, ORCID ID: 0000-0003-3865-2496

${ }^{3}$ Department of General Chemistry, Kharkiv National University of Civil Engineering and Architecture, Sumska str., 40, Kharkiv, Ukraine, 61002, phone: +38 (057) 706-20-81, e-mail: obigenko@ukr.net, ORCID ID: 0000-0002-1409-7515

${ }^{4}$ Department of General Chemistry, Kharkiv National University of Civil Engineering and Architecture, Sumska str., 40, Kharkiv, Ukraine, 61002, phone: +38 (057) 706-20-81, e-mail: knuba.chemistry@ gmail.com, ORCID ID: 0000-0002-2582-8416

${ }^{5}$ Department of Heat and Gas Supply, Ventilation and Use of Secondary Thermal Energy Resources, Kharkiv National University of Civil Engineering and Architecture, Sumska str., 40, Kharkiv, Ukraine, 61002, phone: +38 (057) 700-16-40, e-mail: iliya_ograpiani@ukr.net, ORCID ID: 000-0003-0798-5001

Purpose. Determination of patterns of sorption of $\mathrm{NH}_{4}{ }^{+}$ions on the surface of dispersed clay minerals of various chemical nature (sorbents). Establishing the relationship between the acid-base properties of active centers of the hydroxyl-hydrated surface layer of sorbents and the efficiency of extraction of $\mathrm{NH}_{4}{ }^{+}$ions from aqueous solutions. Method. Modern methods were used to study the surface and physical and chemical properties of clay sorbents: X-ray diffraction analysis, electronic scanning microscopy, potentiometric analysis of aqueous suspensions, spectrophotometric analysis. Studies on the sorption capacity of clay sorbents in relation to $\mathrm{NH}_{4}{ }^{+}$ions were conducted in static conditions. Results. The obtained results of experimental research of mineral composition, surface morphology, dispersion, specific surface, acid-base properties of hydroxyl-hydrated surface layer of disperse clay mineral sorbents. The comparative characteristic of the efficiency of the use of clay sorbents with different chemical nature for the extraction of $\mathrm{NH}_{4}{ }^{+}$ions from aqueous solutions is given. It is established that the sorption ability of clay sorbents increases in a number of bentonite clay > kaolin clay > diabase flour. It was established that the main mechanism of sorption of $\mathrm{NH}_{4}{ }^{+}$ions on the surface of kaolin clay is ion exchange, and on the surface of diabase flour is physical adsorption. In aqueous suspensions of bentonite clay a mixed mechanism is realized: physical adsorption and ion exchange. Scientific novelty. Mechanisms and patterns of sorption of $\mathrm{NH}_{4}{ }^{+}$ions on the surface of clay sorbents: bentonite clay, kaolin clay and diabase flour have been established. The relationship between the mineral composition and the structure of the hydroxyl-hydrated surface layer of sorbents is established. It is shown that the mecha- 
nism of extraction of $\mathrm{NH}_{4}{ }^{+}$ions is due to the quantity and acid-base properties of the surface active centers of the hydroxyl-hydrated layer of sorbents. Practical meaningfulness. The obtained regularities will allow to use more effectively cheap and ecologically attractive disperse clay minerals as sorbents for cleaning liquid and gaseous media from $\mathrm{NH}_{4}{ }^{+}$ions.

\section{Постановка проблеми}

Природні і штучні мінеральні дисперсні сорбенти ефективно використовуються у технологіях очищення водних і газоподібних середовищ від іонів амонію та аміаку [1-9]. Серед природних адсорбентів лідирують алюмосилікати (цеоліти) [1-6], палигорськіти, глауконіти [2], клиноптилоліти [7], бентоніти [8,9]. Використання в очисних технологіях мінеральних сорбентів відповідає вимогам енергозбереження, екологічно чистих технологій виробництва та принципам «зеленої хімії» [10]. Перевагами застосування мінеральних дисперсних сорбентів є низька вартість, що надає можливість виключення 3 технологічного процесу ланки регенерації. Відпрацьовані сорбенти можуть використовуватись для покращення якості грунтів з одночасним внесенням іонів амонію, що $€$ корисним для рослин [3]. Використання мінеральних дисперсних сорбентів дозволить замінити, частково або повністю, синтетичні іонообмінні смоли.

\section{Аналіз останніх досліджень і публікацій}

В останніх наукових дослідженнях проведені визначення адсорбційної здатності різних мінеральних дисперсних сорбентів по відношенню до іонів амонію - базальтового туфу, цеолітів, палигорськіту, глауконіту [1-3]. Встановлено, що найкращі сорбційні властивості виявляють цеоліти [3-5]. Відомо, що для підвищення сорбційних властивостей неорганічних матеріалів ефективно використання хімічних або фізичних методів активації поверхні адсорбентів. У роботі [1] відмічається, що природа поверхневих активних центрів i, відповідно, сорбційні властивості природних алюмосилікатів (базальтового туфу) визначаються хімічним складом та умовами попередньої термічної обробки. Дослідження авторів [9] показали, що опромінення бентоніту надвисоким електромагнітним випромінюванням у поєднанні 3 промивкою очищеною водою може бути перспективним методом підвищення ефективності сорбційної очистки вод від біогенних іонів. У роботі [11] встановлено, що адсорбційна здатність (ємність, коефіцієнт дифузіі, константа рівноваги) природного алюмосилікату (монтморилоніту і клиноптилоліту) збільшується в результаті кислотної активації (обробки поверхні сірчаною кислотою).

У деяких дослідженнях надається ймовірний механізм адсорбції іонів амонію на поверхні неорганічних адсорбентів [6,8,9,11]. Авторами [6] встановлено, що поглинання іонів амонію клиноптилолітом відбувається одночасно за двома механізмами. По-перше, за іонним обміном $\mathrm{NH}_{4}^{+}$на іони $\mathrm{Ca}^{2+} \mathrm{i} \mathrm{Na}^{+}$та по-друге, за механізмом фізичної адсорбції $\mathrm{NH}_{4}^{+}$на льюїсівських основних поверхневих центрах і шляхом заміни молекул води у цеолітовому каркасі. Згідно [8] адсорбція $\mathrm{NH}_{4}{ }^{+}$на поверхні бентонітової глини має фізичну природу. Взаємодія $\mathrm{NH}_{4}{ }^{+} 3$ поверхнею слабка і в мікропорах відбувається капілярна конденсація. Крім цього, показано [9], що механізм сорбції на поверхні бентоніту залежить від чистоти вихідного сорбенту, зокрема, вмісту власних рухливих іонів $\mathrm{NH}_{4}^{+}$. Дослідженнями [11] внаслідок порівняння процесу сорбції іонів $\mathrm{NH}_{4}^{+}$на поверхні природного та кислотноактивованого алюмосилікатних сорбентів встановлено наступне. Іони $\mathrm{NH}_{4}{ }^{+}$з розчину обмінюються на присутні на поверхні сорбентів іони $\mathrm{Na}^{+}, \mathrm{K}^{+}, \mathrm{Ca}^{2+} \mathrm{i} \mathrm{Mg}^{2+}$. Після обробки сорбентів сірчаною кислотою (2,33M) на поверхні відбуваються процеси декатіонування, деалюмінування і розрив зв'язків $\mathrm{Si}-\mathrm{O}-\mathrm{Al}$, в результаті чого утворюються силанольні групи (центри Бренстеда) i трикоординовані атоми алюмінію (центри Льюїса). Новоутворені поверхневі центри здатні додатково приймати участь у сорбції $\mathrm{NH}_{4}{ }^{+}$.

\section{Виділення невирішених раніше частин означеної проблеми}

Враховуючи проведені іншими авторами дослідження, можна стверджувати, що в процесах сорбції іонів $\mathrm{NH}_{4}^{+}$на поверхні глинистих та інших неорганічних природних сорбентах суттєве значення мають поверхневі активні центри Бренстеда і Льюїса. Сукупність активних центрів об'єднується у гідроксильно-гідратний шар центрів Льюїса і Бренстеда, який $€$ результатом хімічної і фізичної адсорбції молекул води на поверхні [12-15]. Очевидно, що підвищення кількості активних центрів на поверхні сприятиме більш ефективній сорбції іонів $\mathrm{NH}_{4}^{+}$, а інтенсивність взаємодії залежатиме від кислотно-основних властивостей вищеозначених центрів. Тому, встановлення закономірностей і механізмів сорбції іонів $\mathrm{NH}_{4}^{+}$на поверхні глинистих сорбентів в залежності від кількості і кислотно-основних властивостей поверхневих активних центрів $є$ важливою науково-практичною задачею. Крім того, необхідна порівняльна характеристика глинистих сорбентів різної хімічної природи щодо сорбційної здатності іонів $\mathrm{NH}_{4}{ }^{+}$.

\section{Формулювання мети статті}

Метою статті є встановлення закономірностей і механізмів сорбції іонів $\mathrm{NH}_{4}{ }^{+}$на поверхні дисперсних глинистих мінералів (сорбентів) різної хімічної природи. З'ясувати взаємозв'язок між кислотноосновними властивостями активних центрів гідроксильно-гідратного поверхневого шару сорбентів та ефективністю вилучення іонів $\mathrm{NH}_{4}^{+}{ }^{+}$водних розчинів.

\section{Викладення основного матеріалу дослідження}

В якості матеріалів для дослідження обрані глинисті дисперсні сорбенти різного хімічного і мінерального складу: бентонітова глина (БГ), каолінова глина (КГ) і діабазова мука (ДП).

Для обраних матеріалів проведені експериментальні дослідження по встановленню мінерального 
складу, дисперсності, морфології поверхні та питомої поверхні частинок. Питома поверхня визначалась методом БЕТ (Брунауера, Еммета, Теллера). Рентгенофазовий аналіз здійснювався на рентгенівському дифрактометрі ДРОН-2 (Росія). Дослідження морфології поверхні та дисперсності проводились за допомогою скануючого електронного мікроскопу марки JSM-6390LV (Японія).

Для характеристики поверхневих кислотноосновних властивостей глинистих сорбентів використовувались два методи.

1) $\mathrm{pK}_{\mathrm{a}}$-метричний експериментальний метод визначення кількості поверхневих активних центрів шляхом адсорбції кольорових індикаторів Гамета 3 водних розчинів і фотоколориметричним вимірюванням оптичної густини. В результаті розраховані показники сумарної кількості кислотних активних центрів $\sum q_{\mathrm{A}} 3 p K_{\mathrm{a}}<7$, основних активних центрів $\sum q_{\mathrm{B}} 3 p K_{\mathrm{a}}>7$, загальна кількість поверхневих центрів $\sum q=\sum q_{\mathrm{A}}+$ $\sum q_{\text {в }}$ і кислотно-основний показник $Q=\sum q_{\mathrm{A}} / \sum q_{\mathrm{B}}$. Отриманий показник дає можливість оцінити поверхню загалом як нейтральну $(Q \approx 1)$, кислотну $(Q>1)$ або основну $(Q<1)$. При цьому вважається, що чим більше значення $Q$, тим більш кислотними властивостями характеризується поверхня. Відповідно, чим менше це значення від 1, тим більш основною є поверхня сорбенту. Показник інтегральної кислотності поверхні $Q$ має певні переваги та недоліки. Основним недоліком є той факт, що значення $Q$ не дозволяє оцінити кислотно-основні властивості поверхні за Льюїсом і для цього необхідні додаткові експериментальні дослідження (наприклад, метод адсорбції молекул газів). Перевагами $є$ можливість більш повного уявлення про кислотно-основну природу поверхні будь-яких дисперсних матеріалів (в тому числі і полімінеральних) в рамках невеликої кількості експериментальних та розрахункових операцій [15].

2) рН-метричний експериментальний метод 3 потенціометричним вимірюванням $p H^{\mathrm{p}}{ }_{\mathrm{c}}$ водних суспензій сорбентів у процесі встановлення рівноважного стану. 3 урахуванням $p H$ чистої води $\left(p H_{0}\right)$ та $p H$ суспензій у рівноважному стані $\left(p H^{\mathrm{p}}{ }_{\mathrm{c}}\right)$, розраховувались величини $p H_{\text {IIт }}$ водних суспензій, які відповідають середньоарифметичному показнику $\mathrm{pK}_{\mathrm{a}}$ поверхневих активних центрів:

$$
\begin{gathered}
p H_{\mathrm{IIT}}=1 / n \cdot \sum_{i=1}^{n}(p K a 1+p K a 2+\ldots+p K a i), \\
p H_{\mathrm{IIT}}=p H_{0}+\left(p H_{\mathrm{c}}^{\mathrm{p}}-p H_{0}\right) \cdot\left(p H_{0}-6\right)
\end{gathered}
$$

Для наближеної оцінки спектру активних поверхневих центрів розраховувалось значення $\Delta p H=p H_{\text {IIT }}-$ $p H^{\mathrm{p}}$, яке свідчить про ширину діапазону $p K_{\mathrm{a}}$ центрів на поверхні. Збільшення значення $\Delta p H$ показує розширення спектру активних центрів за показником $p K_{\mathrm{a}}$ на поверхні. Для наближеної кількісної оцінки активних центрів поверхні за даними потенціометричних досліджень встановлювалась тривалість часу встановлення рівноважного стану у суспензії. Ця величина може характеризувати загальну кількість ки- слотно-основних поверхневих активних центрів, які приймають участь у взаємодіях з молекулами води.

Результати дослідження мінерального складу, дисперсності та питомої поверхні глинистих сорбентів представлені у табл. 1, 2 і на рис. 1-3.

Таблицяя 1

Мінеральний склад глинистих сорбентів / Mineral

\begin{tabular}{|c|c|}
\hline Сорбент & Мінеральний склад \\
\hline $\begin{array}{c}\text { Глина бентонітова (БГ), } \\
\text { ГОСТ 28177-89 }\end{array}$ & $\begin{array}{c}\text { Монтморилоніт } \\
(\mathrm{Al}, \mathrm{Mg})_{2}(\mathrm{OH})_{2}\left[\mathrm{Si}_{4} \mathrm{O}_{10}\right] \mathrm{nH}_{2} \mathrm{O}^{\bullet} \\
\beta \text {-кварц } \mathrm{SiO}_{2}^{+} \\
\text {Каолініт } \mathrm{Al}_{2} \mathrm{Si}_{2} \mathrm{O}_{5}(\mathrm{OH})_{4}^{+}\end{array}$ \\
\hline $\begin{array}{c}\text { Каолінова глина Глухо- } \\
\text { вецького родовища (КГ), } \\
\text { ГОСТ } 21286-82\end{array}$ & $\begin{array}{c}\text { Каолініт } \mathrm{Al}_{2} \mathrm{Si}_{2} \mathrm{O}_{5}(\mathrm{OH})_{4}{ }^{-} \\
\beta \text {-кварц } \mathrm{SiO}_{2}{ }^{+} \\
\text {Біотит } \\
(\mathrm{Fe}, \mathrm{Mg})_{3}[\mathrm{OH}]_{2}(\mathrm{Al}, \mathrm{Fe}) \mathrm{Si}_{3} \mathrm{O}_{10}{ }^{+} \\
\Gamma \text { гідрослюда } \\
(\mathrm{K}, \mathrm{Na}) \mathrm{Al}_{2}(\mathrm{Si}, \mathrm{Al})_{4} \mathrm{O}_{10}(\mathrm{OH})_{2} \mathrm{nH}_{2} \mathrm{O}^{+}\end{array}$ \\
\hline $\begin{array}{c}\text { Діабазова мука } \\
\text { (ДП), } \\
\text { ТУ 5716-001-41357914- } \\
2009\end{array}$ & $\begin{array}{c}\beta \text {-кварц } \mathrm{SiO}_{2}{ }^{\bullet} \\
\text { Монтмориллоніт } \\
(\mathrm{Al}, \mathrm{Mg})_{2}(\mathrm{OH})_{2}\left[\mathrm{Si}_{4} \mathrm{O}_{10}\right] \mathrm{nH}_{2} \mathrm{O}^{\bullet} \\
\text { Ортоклаз } \mathrm{K}_{2} \mathrm{O}^{\circ} \mathrm{Al}_{2} \mathrm{O}_{3} \cdot 6 \mathrm{SiO}_{2} \\
\text { Лейцит } \mathrm{K}_{2} \mathrm{O}^{\cdot} \mathrm{Al}_{2} \mathrm{O}_{3} \cdot 4 \mathrm{SiO}_{2} \\
\text { Лимоніті } \mathrm{Fe}_{2} \mathrm{O}_{3} \cdot \mathrm{H}_{2} \mathrm{O}^{+}\end{array}$ \\
\hline
\end{tabular}
composition of clay sorbents

Примітка: • - основна мінеральна фаза; + - побічна мінеральна фаза; * - сліди.

Таблиия 2

Властивості глинистих сорбентів / Properties of clay sorbents

\begin{tabular}{|c|c|c|}
\hline Сорбент & $\begin{array}{c}\text { Питома поверхня } \\
\mathrm{S}, \mathrm{M}^{2} / \Gamma\end{array}$ & $\begin{array}{c}\text { Середній розмір } \\
\text { частинок d, мкм }\end{array}$ \\
\hline БГ & 15,62 & $10-20$ \\
\hline$Д П$ & 1,90 & $2-4$ \\
\hline КГ & 8,78 & $4-5$ \\
\hline
\end{tabular}

Рентгенограма бентонітової глини представлена набором дифузних дифракційних максимумів слабкої інтенсивності, які відповідають мінералам монтморилонітової групи (монтморилоніту і бейделіту). Супутніми виступають каолініт і $\beta$-кварц. На мікрофотографіях видно лускаті зерна глинистих мінералів і окремі ромбоедричні зерна кварцу з розміром 1-1,5 мкм. Лускаті зерна глинистих мінералів розміром менше 0,5 мкм зібрані в агрегати розміром 10-20 мкм, зустрічаються окремі великі (50-60 мкм) частинки. Каолінова глина - дисперсний мінеральний матеріал жовтуватого кольору. В якості супутніх мінералів у складі порошку присутні гідрослюда, біотит $(\mathrm{Fe}, \mathrm{Mg})_{3}[\mathrm{OH}]_{2}(\mathrm{Al}, \mathrm{Fe}) \mathrm{Si}_{3} \mathrm{O}_{10}$ і $\beta$-кварц (табл. 1). Порошок має однорідний дисперсний склад (рис. 2). На мікрофотографіях видно агломерати розміром 4-5 мкм, які утворені з лускатих кристалів каолініту кристалів гідрослюди 3 розміром 0,5-1 мкм. Рідше зустрічаються великі щільні ізометричні частинки кварцу розміром 10-12 мкм. Мікрофотографії діабазової муки представлені на рис. 3. 


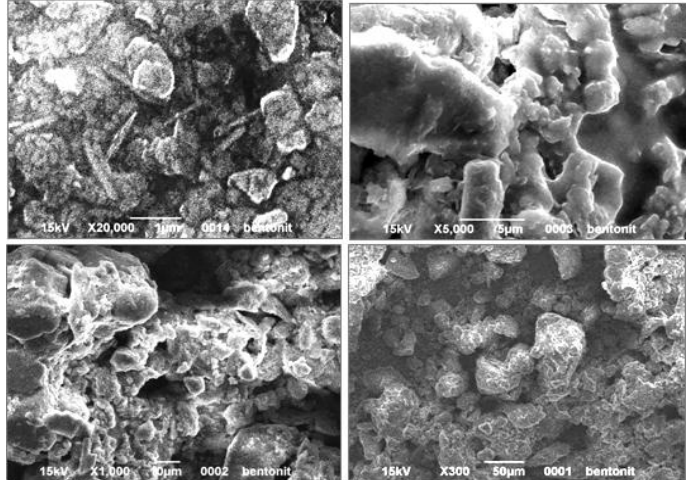

Рис. 1. Мікрофотографії частинок глини бентонітової / Microphotographs particles of clay bentonite
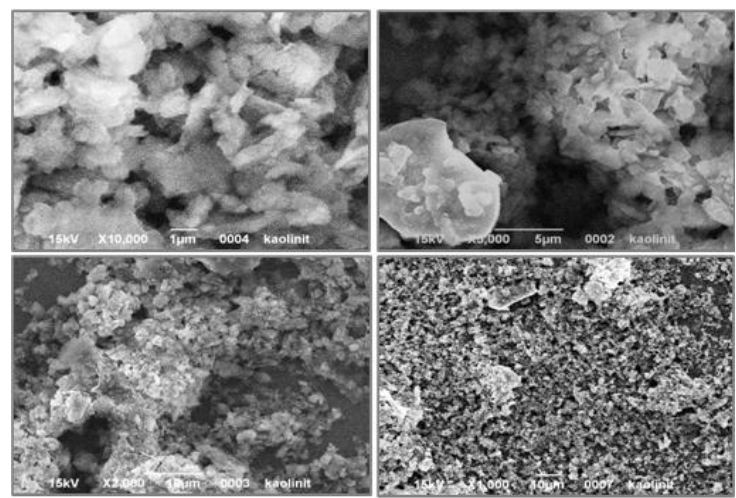

Рис. 2. Мікрофотографії частинок глини каолінової / Microphotographs particles of clay kaoline

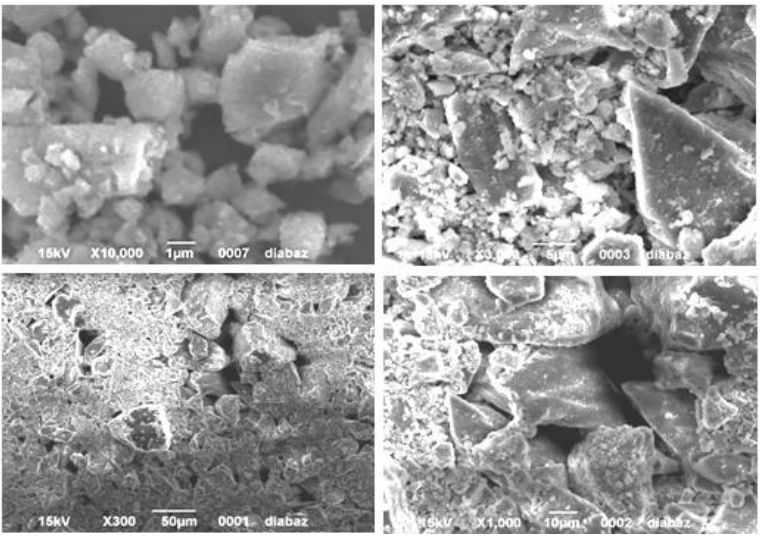

Рис. 3. Мікрофотографї частинок діабазової муки / Microphotographs particles of diabase flour

Діабазова мука - продукт дрібного помелу у кульових млинах кислотостійкої магматичної гірничої породи (діабазу). Містить у якості основних фаз лейцит $\mathrm{K}_{2} \mathrm{O}^{*} \mathrm{Al}_{2} \mathrm{O}_{3} \cdot 4 \mathrm{SiO}_{2}$, ортоклаз $\mathrm{K}_{2} \mathrm{O}^{*} \mathrm{Al}_{2} \mathrm{O}_{3} \cdot 6 \mathrm{SiO}_{2}$, кварц $\mathrm{SiO}_{2}$, монтморилоніт $(\mathrm{Al}, \mathrm{Mg})_{2}(\mathrm{OH})_{2}\left[\mathrm{Si}_{4} \mathrm{O}_{10}\right] \cdot \mathrm{nH}_{2} \mathrm{O}$ i лимоніт $\mathrm{Fe}_{2} \mathrm{O}_{3} \cdot \mathrm{H}_{2} \mathrm{O}$ (табл. 1). Частинки ізометричні, зібрані в агломерати 3 розміром 2-4 мкм. Великі частинки 3 розміром 40-50 мкм мають раковистий злам, вкриті лускатими утвореннями монтморилоніту i лимоніту.Результати рК-метричного і рН-метричного експериментальних досліджень глинистих сорбентів представлені у табл. 3 і 4 .
Результати дослідження глинистих сорбентів рКметричним методом / Results of study of clay sorbents by pK-metric method

\begin{tabular}{|c|c|c|c|c|}
\hline Сорбент & $\begin{array}{c}\sum \mathrm{q}_{\mathrm{A}} \cdot 10^{-12} \\
1 / \mathrm{cm}^{2}\end{array}$ & $\begin{array}{c}\sum \mathrm{q}_{\mathrm{B}} \cdot 10^{-12} \\
1 / \mathrm{cm}^{2}\end{array}$ & $\begin{array}{c}\sum \mathrm{q} \cdot 10^{-12} \\
1 / \mathrm{cm}^{2}\end{array}$ & $\mathrm{Q}$ \\
\hline БГ & 108,26 & 119,03 & 227,29 & 0,91 \\
\hline ДП & 148,55 & 185,23 & 333,78 & 0,80 \\
\hline КГ & 78,18 & 120,93 & 199,11 & 0,65 \\
\hline
\end{tabular}

Таблиия 4

Результати дослідження глинистих сорбентів рНметричним методом / Results of study of clay sorbents by pH-metric method

\begin{tabular}{|c|c|c|c|c|c|}
\hline Сорбент & $\mathrm{pH}_{0}$ & $\mathrm{pH}_{\mathrm{c}}^{\mathrm{p}}$ & $\mathrm{pH}_{\text {IIт }}$ & $\Delta \mathrm{pH}$ & $\begin{array}{c}\text { Тривалість } \\
\text { встановлення } \\
\text { рівноважного } \\
\text { стану, с }\end{array}$ \\
\hline БГ & 7,05 & 7,44 & 7,46 & 0,02 & 300 \\
\hline ДП & 7,00 & 8,50 & 8,50 & 0 & 360 \\
\hline КГ & 7,00 & 9,11 & 9,11 & 0 & 240 \\
\hline
\end{tabular}

3 даних табл. 3 випливає, що кислотність поверхні глинистих сорбентів суттєво залежить від мінерального складу. Мінеральний склад БГ і КГ є майже однорідним і представлений домінуючими мінералами монтморилонітом і каолінітом відповідно. Очевидно, що наявність цих мінералів надають майже нейтральний характер поверхні БГ $(Q \approx 0,91)$ і слабко основний КГ $(Q \approx 0,65)$. До складу ДП входять декілька мінералів: лейцит, ортоклаз, монтморилоніт і кварц 3 домішками лимоніту. Характер поверхні ДП займає проміжне значення і близький до нейтрального $(Q \approx 0,80)$. Збільшення лужності поверхні ДП в порівнянні з БГ пов'язано з присутністю мінералів лейциту та ортоклазу, до складу яких входить оксид калію $\mathrm{K}_{2} \mathrm{O}$. Додатково лужність можуть надавати домішки лимоніту, до складу якого входить оксид феруму $\mathrm{Fe}_{2} \mathrm{O}_{3}$. Таким чином, за результатами рК-метричного дослідження, кислотність поверхні глинистих сорбентів зростає у ряду:

$$
K \Gamma(Q \approx 0,65)<Д \Pi(Q \approx 0,80)<Б Г(Q \approx 0,91) .
$$

Щодо кислотно-основного характеру поверхні, результати рК-метричного дослідження повністю підтверджуються даними рН-метричного аналізу. Так 3 даних, представлених у табл. 4 випливає, що кислотність поверхні глинистих сорбентів, відповідно до значення $\mathrm{pH}_{\mathrm{IIT}}$, зростає у ряду:

$$
\text { КГ }(9,11)<Д \Pi(8,50)<Б Г(7,46) .
$$

Враховуючи повне співпадіння отриманих порівняльних рядів 4 і 5 можна зробити висновок, що визначальним фактором у кислотно-основних поверхневих властивостях глинистих сорбентів $є$ мінеральний склад.

3 даних табл. 3 видно, що найбільшою кількістю активних центрів характеризується поверхня ДП ( $\sum q$ $\left.=333,78 \cdot 10^{12} 1 / \mathrm{cm}^{2}\right)$. Це корелює 3 найбільшою тривалістю часу встановлення рівноважного стану у во- 
дних суспензіях ДП (360 с). Необхідно також відмітити, що і для сорбентів БГ і КГ ці показники також узгоджуються: чим більша загальна кількість поверхневих активних центрів, тим більшою є тривалість часу встановлення рівноважного стану у водних суспензіях.

За результатами табл. 4 спектр активних поверхневих центрів глинистих сорбентів не є широким. Цей висновок випливає з того, що величини $\Delta p H$ дорівнюють нулю або близькі до нуля. Тому більшість поверхневих активних центрів глинистих сорбентів, мабуть, мають близькі значення $p K_{a}$.

Спектри $\mathrm{pK}$ активних поверхневих центрів ДП і КГ представлені на рис. 4.

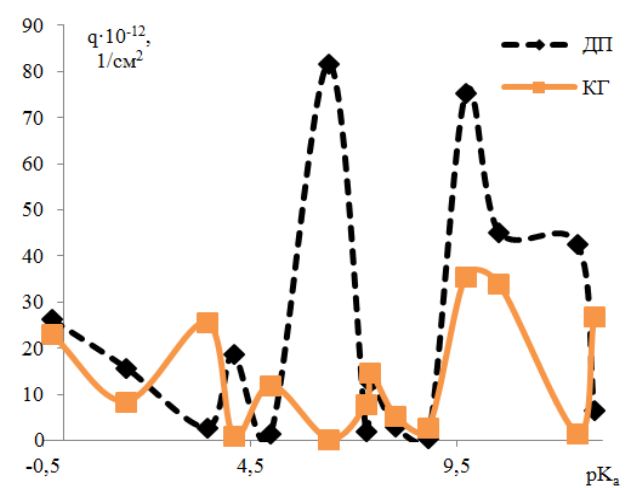

Pис.4. рК-спектри активних иенттів на поверхні діабазової муки і каолінової глини / pK spectra of active centers on the surface of diabase flour and kaolin clay

Порівняльна характеристика результатів, що представлені на рис. 4 та у табл. 4 свідчить про те, що вивчення $\mathrm{pK}$-спектрів потенціометричним $\mathrm{pH}$ метричним методом не $\epsilon$ інформативним. Цей метод, на відміну від рК-метричного, не надає повної інформації щодо розподілу активних центрів за кислотноосновним показником $\mathrm{pK}$, тобто кислотною силою. Так, за результатами рК-метричного дослідження (рис. 4), поверхня ДП майже нейтральна з переважаючою кількістю (більше $80 \%$ ) двох видів центрів: нейтральних $p K_{a} \approx 7$ та сильно основних $p K_{a} \approx 9-12$. Поверхня КГ відрізняється у 2,5 рази меншою питомою кількістю активних центрів і слабко основним характером. Схожим є те, що майже 50 \% усіх поверхневих активних центрів ДП і КГ приходиться на сильно основні (лужні) центри $3 ~ p K_{a} \approx 9-12$. Умовний кількісний розподіл активних центрів по поверхні представлений у табл. 5.

Табличя 5

Кількісний розподіл поверхневих активних центрів / Quantitative distribution of surface active centers

\begin{tabular}{|c|c|c|c|}
\hline \multirow{2}{*}{$\begin{array}{c}\text { Cop- } \\
\text { бент }\end{array}$} & \multicolumn{3}{|c|}{ Відносна кількість поверхневих активних центрів в } \\
\cline { 2 - 4 } & $\begin{array}{c}\text { Кислотнивал } \\
(-0,29-5,0)\end{array}$ & $\begin{array}{c}\text { Нейтральних } \\
(6,4-7,4)\end{array}$ & $\begin{array}{c}\text { Основних } \\
(8,0-12,8)\end{array}$ \\
\hline ДП & 19,5 & 28,8 & 51,7 \\
\hline КГ & 35,2 & 11,5 & 53,3 \\
\hline
\end{tabular}

3 представлених у табл. 5 результатів видно, що на поверхні КГ майже у 2 рази, в порівнянні з ДП, переважає кількість кислотних центрів. Основні (лужні) центри на поверхні обох сорбентів переважають і складають приблизно однакову кількість (близько 50 \%), що і зазначалось вище. Нейтральних центрів більше на поверхні ДП у 2,5 рази.

Дослідження сорбційної здатності глинистих сорбентів по відношенню до іонів $\mathrm{NH}_{4}^{+}$у статичних умовах проводились при співвідношенні сорбенту до водного розчину Т:Ж=1:100 [16]. Для цього в стакани приливались $V_{\text {розч }}=0,05$ дм $^{3}$ розчинів хлориду амонію $\mathrm{NH}_{4} \mathrm{Cl} 3$ різною початковою концентрацією іонів $\mathrm{NH}_{4}{ }^{+}\left(C_{\text {вих }}=0,011-0,099\right.$ мг-екв $\left.\mathrm{NH}_{4}{ }^{+} /{ }^{2}{ }^{3}\right)$ та додавались наважки сорбентів масою $m=0,5$ г. Тривалість контакту сорбентів з водним середовищем складала 2 години при безперервному перемішуванні за допомогою магнітної мішалки. Значення тривалості контакту обумовлене дослідженнями роботи [1], де встановлено, що за 2 години процеси адсорбції і іонообміну на поверхні глинистих сорбентів за участю $\mathrm{NH}_{4}{ }^{+}$відбуваються повністю. Після відділення твердої фази у маточному розчині визначалась залишкова концентрація $\mathrm{NH}_{4}{ }^{+}\left(C_{\text {рівн }}\right)$ фотоколориметричним методом 3 реактивом Неслера у відповідності до методики [17]. За результатами досліджень розраховувалась адсорбція $A$ іонів $\mathrm{NH}_{4}^{+}$у мг-екв $\mathrm{NH}_{4}{ }^{+} / \mathrm{M}^{2}$ за формулою:

$$
A=\left(C_{\text {вих }}-C_{\text {рівн }}\right) \cdot V_{\text {розч }} / 1000 \cdot m \cdot S
$$

Величина питомої поверхні сорбенту $S$ включається у формулу адсорбції з метою встановлення взаємозв'язків між адсорбцією іонів $\mathrm{NH}_{4}{ }^{+}$, кількістю i кислотно-основними властивостями поверхневих активних центрів сорбентів. За результатами розрахунків будувались ізотерми сорбції у статичних умовах - графіки залежності $A=f\left(C_{\text {вих }}\right)$. Потенціометричним методом вимірювалась величина $\mathrm{pH}$ маточного розчину до і після адсорбції.

Одержані результати наведені на рис. 5 і у табл. 6.

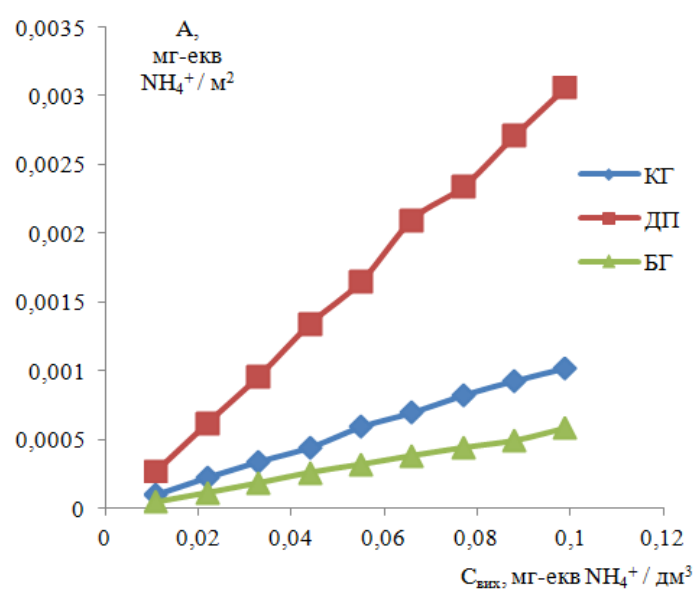

Рис.5. Ізотерми адсорбиії на поверхні глинистих сорбентів з водних розчинів $\mathrm{NH}_{4} \mathrm{Cl}$ у статичних умовах / Isotherms of adsorption on the surface of clay sorbents from aqueous solutions $\mathrm{NH}_{4} \mathrm{Cl}$ in static conditions 
Таблиия 6

Кислотність маточного розчину $\mathrm{NH}_{4} \mathrm{Cl}$ до і після адсорбції / Acidity of the mother liquor $\mathrm{NH}_{4} \mathrm{Cl}$ before and after adsorption

\begin{tabular}{|c|c|c|}
\hline $\begin{array}{l}C_{\text {вих }}, \text { мг-екв } \\
\mathrm{NH}_{4}^{+} / \text {дм }^{3}\end{array}$ & $\mathrm{pH}_{\text {вих }}$ & $\mathrm{pH}_{\text {кін }}$ \\
\hline \multicolumn{3}{|c|}{ Бентонітова глина } \\
\hline 0,011 & 6,69 & 6,85 \\
\hline 0,022 & 6,52 & 6,88 \\
\hline 0,033 & 6,47 & 6,92 \\
\hline 0,044 & 6,58 & 6,72 \\
\hline 0,055 & 6,67 & 6,74 \\
\hline 0,066 & 6,72 & 6,78 \\
\hline 0,077 & 6,68 & 6,85 \\
\hline 0,088 & 6,78 & 7,25 \\
\hline 0,099 & 6,84 & 7,12 \\
\hline \multicolumn{3}{|c|}{ Діабазова мука } \\
\hline 0,011 & 6,17 & 7,15 \\
\hline 0,022 & 6,22 & 7,07 \\
\hline 0,033 & 6,31 & 7,05 \\
\hline 0,044 & 6,42 & 7,09 \\
\hline 0,055 & 6,63 & 7,25 \\
\hline 0,066 & 6,71 & 7,11 \\
\hline 0,077 & 6,77 & 7,17 \\
\hline 0,088 & 6,79 & 7,14 \\
\hline 0,099 & 6,82 & 7,34 \\
\hline \multicolumn{3}{|c|}{ Каолінова глина } \\
\hline 0,011 & 6,29 & 6,16 \\
\hline 0,022 & 6,20 & 6,14 \\
\hline 0,033 & 6,15 & 6,12 \\
\hline 0,044 & 6,75 & 6,03 \\
\hline 0,055 & 6,83 & 5,92 \\
\hline 0,066 & 6,84 & 5,96 \\
\hline 0,077 & 6,86 & 6,15 \\
\hline 0,088 & 6,92 & 6,12 \\
\hline 0,099 & 6,96 & 6,03 \\
\hline
\end{tabular}

Як видно з представлених результатів, залежності $A=f\left(C_{\text {вих }}\right)$ для усіх глинистих сорбентів в досліджуваному інтервалі концентрацій мають прямо пропорційний характер. Цей факт підтверджується результатами експериментів інших авторів $[6,8,11]$.

Як випливає 3 результатів рис. 5, ефективність вилучення іонів $\mathrm{NH}_{4}^{+}$зростає у ряду: БГ > КГ > ДП. Складність порівняльного аналізу отриманих даних пов'язана 3 тим, що глинисті сорбенти мають різну морфологічну структуру (рис. 1-3), з якою, вірогідно, пов'язані механізми вилучення іонів $\mathrm{NH}_{4}{ }^{+}$. Як було встановлено $[6,8]$, вилучення іонів $\mathrm{NH}_{4}{ }^{+}$бентонітовою глиною відбувається за двома механізмами: фізичної адсорбції і іонним обміном. Крім того, показано, що відбувається дифузія іонів $\mathrm{NH}_{4}{ }^{+}$у міжшаровий простір пластинчатих бентонітових частинок, де відбувається заміщення молекул води. Не дивлячись на це, отримані дані (рис. 5) свідчать про те, що БГ, в порівнянні з КГ і ДП, є найгіршим сорбентом для іонів $\mathrm{NH}_{4}^{+}$. Найбільш логічним $є$ порівняння сорбційних властивостей ДП і КГ. Якщо припустити, що на поверхні цих сорбентів також реалізуються обидва механізми, можна зробити наступні висновки. Фізична адсорбція позитивно заряджених іонів $\mathrm{NH}_{4}^{+}$може відбуватись на основних (лужних) центрах Льюїса $-\mathrm{MeO}^{-}$і на іонізованих кислотних і слабкокислотних центрах Бренстеда $\left.-\mathrm{Me}(\mathrm{OH})_{2}\right)^{-}$. При цьому $\mathrm{pH}$ маточних розчинів, очевидно, підвищується внаслідок вивільнення іонів $\mathrm{OH}^{-}$. Іонний обмін на поверхні сорбентів може здійснюватись за рахунок обміну іонів $\mathrm{NH}_{4}^{+}$на іони $\mathrm{H}^{+}$за участю кислотних центрів Бренстеда. При цьому рН маточних розчинів знижується внаслідок збільшення концентрації іонів $\mathrm{H}^{+}$.

Зважаючи на вищевикладені припущення і висновки, а також результати табл. 6, можна сформулювати наступне. Очевидно, що вилучення іонів $\mathrm{NH}_{4}{ }^{+}$на поверхні КГ відбувається переважно за механізмом іонного обміну. Це підтверджується наявністю великої кількості кислотних активних центрів (табл. 5), які здатні заміщувати іон $\mathrm{H}^{+}$, а також зниженням $\mathrm{pH}$ маточних розчинів після адсорбції (табл. 6). Вилучення іонів $\mathrm{NH}_{4}^{+}$поверхнею ДП, очевидно, відбувається переважно за механізмом фізичної адсорбції. Іони $\mathrm{NH}_{4}^{+}$адсорбуються на іонізованих кислотних $\mathrm{i}$ слабко кислотних активних центрах (табл. 5), а також на основних (лужних) центрах Бренстеда і Льюїса (табл. 5, рис. 4). При цьому $\mathrm{pH}$ маточних розчинів після адсорбції зростає (табл. 6). В суспензіях БГ для вилучення іонів $\mathrm{NH}_{4}{ }^{+}$, очевидно, реалізується обидва механізми, що підтверджується отриманими результатами.

\section{Висновки}

В результаті проведених досліджень встановлені механізми та закономірності вилучення 3 водних розчинів іонів $\mathrm{NH}_{4}^{+}$на поверхні глинистих сорбентів: бентонітової глини, каолінової глини і діабазової муки. Встановлені взаємозв'язки між мінеральним складом і будовою гідроксильно-гідратного поверхневого шару сорбентів. Показано, що механізм вилучення іонів $\mathrm{NH}_{4}^{+}$обумовлений кількістю і кислотноосновними властивостями поверхневих активних центрів гідроксильно-гідратного шару сорбентів. Встановлено, що основним механізмом сорбції іонів $\mathrm{NH}_{4}{ }^{+}$на поверхні каолінової глини є іонний обмін, на поверхні діабазової муки - фізична адсорбція, на поверхні бентонітової глини реалізується змішаний механізм.

\section{СПИСОК ВИКОРИСТАНИХ ДЖЕРЕЛ}

1. Цимбалюк В. В. Вплив термічної обробки на сорбційні властивості базальтового туфу / В. В. Цимбалюк, А. Г. Волощук, І. М. Кобаса // Укр. хім. журнал. - 2009. - Т. 25, № 12. - С. 85-90.

2. Ватин Н. И. Особенности сорбционно-каталитической очистки воздуха в помещениях обитания человека в условиях крупных городов / Н.И. Ватин, В.Н. Чечевичкин, А.В. Чечевичкин // Инженерно-строительный журнал. - 2011. - № 1. - С. 24-27.

3. Malyovanyy M. Some kinetic regularities of intracellular substance extracting / M. Malyovanyy, G. Sakalova, N. Chornomaz, O. Nahurskyy // Chemistry and chemical technology. - 2013. - Vol.7, №3. - P. 198-208. 
4. Langwaldt J. Ammonium removal from water by eight natural zeolites: a comparative study / J. Langwaldt // Separation Science and Technology. - 2008. - № 43(8). - p. 2166-2182.

5. Demir A. Ammonium removal from aqueous solution by ion-exchange using packed bed natural zeolite / A. Demir, A. Günay, E. Debik // Water SA. - 2002. - № 28(3). - p. 329-336.

6. Гумницький Я. М. Механізм адсорбції іонів амонію природними алюмосилікатами / Я. М. Гумницький, В. В. Сабадаш, Г. А. Тижбір // Вісник національного університету «Львівська політехніка». - 2011. - № 700. - С. 308-310.

7. Taneva N. Removal of Nutrients from Water by Modified Bulgarian Clinoptilolite / N. Taneva, G. Mihailov // BALWOIS 2010. - Ohrid, Republic of Macedonia. - 2010.

8. Петрова М. А. Адсорбційно-бар'єрні властивості бентоніту Язівського родовища як матеріалу протифільтраційних екранів / М. А. Петрова, М. О. Постнікова, К. В. Степова // Восточно-Европейский журнал передовых технологий. - 2014. № 5/10(71). - С. 36-41.

9. Концур А. 3. Сорбція біогенних аніонів на бентоніті, стимульованому надвисокочастотним електромагнітним випромінюванням / А. 3. Концур, Л. В. Сиса // Вісник ЛДУ БЖД. - 2016. - №13. - С. 87-92.

10. Anastas, P. T. Green Chemistry: Theory and Practice / J.C. Warner. - New York: Oxford University Press, 1998. - p. 30.

11. Лы Тхи Иен Кинетика и сорбционное равновесие ионов аммония на природном и кислотноактивированном алюмосиликатном сорбенте $\mathrm{M}_{45} \mathrm{~K}_{20}$ / Лы Тхи Иен, В. Ю. Хохлов, В. Ф. Селеменев, Л. И. Бельчинская // Сорбционные и хроматографические процессы. - 2011. - Т. 11, Вып. 3. - С. 382-390.

12. Danchenko, Yu. Investigation into acid-basic equilibrium on the surface of oxides with various chemical nature / Yu. Danchenko, V. Andronov, E. Rybka, S. Skliarov // Eastern-European Journal of Enterprise Technologies. - 2017. - Vol. 4, Issue 12(88). - P. 17-25.

13. Тарасевич Ю. И. Поверхностные явления на дисперсных матеріалах / Ю. И. Тарасевич. - К.: Наук. думка, 2011. $390 \mathrm{c}$.

14. Горбань О. А. Использование высокого гидростатического давления для управления пористой структурой и состоянием поверхности наночастиц диоксида циркония / О. А. Горбань, С. А. Синякина, В. А. Глазунова, С. В. Горбань, Р. А. Яковлева, Е. Ю. Спирина, Ю. М. Данченко, Т. Е. Константинова // Наносистеми, наноматеріали, нанотехнології. - 2012. - Т. 10, Вип.1. - С. 39-45.

15. Данченко Ю. М. Комплексна оцінка кислотно-основних властивостей поверхні дисперсних оксидних наповнювачів / Ю. М. Данченко, М. П. Качоманова // Науковий вісник будівництва. - 2016. - Т. 86, № 4. - С. 164-172.

16. Шкуткова Е. В. Применение гидроксилапатита для дефторирования воды / Е. В. Шкуткова, Ю. И. Тарасевич // Химия и технология воды. - 2004. - Т.26, №6. - С. 556-566.

17. Лурье Ю. Ю. Аналитическая химия промышленных сточных вод / Ю. Ю. Лурье. - М.: Химия, 1984. - 448 с.

\section{REFERENCES}

1. Tsymbalyuk V. V., Voloshchuk A. H., Kobasa I. M. Vplyv termichnoi obrobky na sorbtsiini vlastyvosti bazaltovoho tufu [Influence of thermal treatment on the sorption properties of basalt tufa]. Ukrainskii Khimichnyi Zhurnal [Ukrainian Chemical Journal]. 2009, V. 25, № 12, pp. 85-90 (in Ukranian).

2. Vatin N. I., Chechevichkin V. N., Chechevichkin A. V. Osobennosti sorbtsionno-kataliticheskoi ochistki vozdukha v pomeshcheniyakh obitaniya cheloveka $v$ usloviyakh krupnukh gorodov [Features of sorption-catalytic air purification in human habitats in large cities]. Inzhenerno-stroitelnyi zhurnal [Engineering and Construction Journal]. 2011, № 1, pp. 24-27 (in Russian).

3. Malyovanyy M., Sakalova G., Chornomaz N., Nahurskyy O. Some kinetic regularities of intracellular substance extracting. Chemistry and chemical technology. 2013, Vol.7, №3, pp. 198-208.

4. Langwaldt J. Ammonium removal from water by eight natural zeolites: a comparative study. Separation Science and Technology. 2008, № 43(8), pp. 2166-2182.

5. Demir A., Günay A., Debik E. Ammonium removal from aqueous solution by ion-exchange using packed bed natural zeolite. Water SA. 2002, № 28(3), pp. 329-336.

6. Humnytskyi Ya. M., Sabadash V. V., Tyzhbir H. A. Mekhanizm adsorbtsii ioniv amoniyu pryrodnymy alyumosylikatamy [Mechanism of adsorption of ammonium ions by natural aluminosilicates]. Visnyk natsionalnoho universytetu "Lvivska politekhni$k a$ ” [Bulletin of the National University "Lviv Polytechnic"]. 2011, № 700, pp. 308-310 (in Ukraine).

7. Taneva N., Mihailov G. Removal of Nutrients from Water by Modified Bulgarian Clinoptilolite. BALWOIS 2010. Ohrid, Republic of Macedonia. 2010, pp. 126.

8. Petrova M. A., Postnikova M. O., Stepova K. V. Adsorbtsiino-baryerni vlastyvosti bentonitu Yazivskoho rodovyshcha yak materialu protyfiltratsiinykh ekraniv [Adsorption-barrier properties of bentonite of Yazivsky deposit as a material of anti-filtration screens] Vostochno-Evropeiskii zhurnal peredovykh tekhnologii [Eastern-European Journal of Enterprise Technologies]. 2014, № 5/10(71), pp. 36-41 (in Ukrainian).

9. Kohtsur A. Z., Sysa L. V. Sorbtsiya biohennykh anioniv na bentoniti, stymulyovanomu nadvysokochastotnym elektromahnitnym vyprominyuvannyam [Sorption of biogenic anions on bentonite, stimulated by ultrahigh-frequency electromagnetic radiation]. Visnyk LDU BZHD [Bulletin of Lviv State University of Life Safety]. 2016, №13, pp. 87-92 (in Ukraine).

10. Anastas P. T. Green Chemistry: Theory and Practice. J.C. Warner. New York: Oxford University Press, 1998, 30p.

11. Ly Tkhi Iien, Khokhlov V. Yu., Selemenev V. F., Belchinskaia L. I. Kinetika I sorbtsionnoie ravnovesiie ionov ammonia na prirodnom I kislotnoaktivirovannom alumosilikatnom sorbente $M_{45} K_{20}$ [Kinetics and sorption equilibrium of ammonium ions on natural and acid-activated aluminosilicate sorbent $\mathrm{M}_{45} \mathrm{~K}_{20}$ ]. Sorbtsionnyie I khromatograficheskiie protsessy [Sorption and chromatographic processes]. 2011, V. 11, Is. 3, pp. 382-390 (in Russian). 
Серия: Безопасность жизнедеятельности. Вып. 105 - 2018

12. Danchenko Yu., Andronov V., Rybka E., Skliarov S. Investigation into acid-basic equilibrium on the surface of oxides with various chemical nature. Eastern-European Journal of Enterprise Technologies. 2017, Vol. 4, Is. 12(88), pp. 17-25.

13. Tarasevich Yu. I. Poverkhnostnyie yavleniia na dispersnykh materialakh [Surface phenomena on dispersed materials]. Kyiv, Naukova dumka, 2011, 390p. (in Russian).

14. Gorban O. A., Siniakina S. A., Glazunova V. A., Gorban S. V., Yakovleva R. A., Spirina Ye. Yu., Danchenko Yu. M., Konstantinova T. Ye. Ispolzovaniie vysokigo gidrostaticheskogo davleniia dlia upravleniia poristoi strukturoi I sostoianiem poverkhnosti nanochastits dioksida tsirkoniia [The use of high hydrostatic pressure to control the porous structure and the surface state of the zirconia oxide nanoparticle]. Nanosystemy, nanomaterialy, nanotekhnolohii [Nanosystems, nanomaterials, nanotechnology]. 2012, V. 10, Is.1, pp. 39-45 (in Russian).

15. Danchenko Yu. M., Kachomanova M. P. Kompleksna otsinka kyslotno-osnovnykh vlastyvostei poverkhni dyspersnykh oksydnykh napovniuvachiv [Comprehensive evaluation of the acid-base properties of the surface of disperse oxide fillers]. Naukovyi visnyk budivnytstva [Scientific Bulletin of Building]. 2016, V. 86, № 4, pp. 164-172 (in Ukrainian).

16. Shkutkova Ye. V., Tarasevich Yu. I. Primeneniie gidriksilapatita dlia deftorirovaniia vody [The use of hydroxyapatite for water defluorination]. Khimiia I tekhnologiia vody [Water chemistry and technology]. 2004, V.26, №6, pp. 556-566 (in Russian).

17. Lurie Yu. Yu. Analiticheskaia khimiia promyshlennykh stochnykh vod [Analytical chemistry of industrial wastewater]. Moskva, Khimiia, 1984, 448 p. (in Russian).

Надійшла до редколегії: 25.09.2018p. 